\title{
REALITAS SOSIAL DALAM PUISI KELUARGA KHONG GUAN KARYA JOKO PINURBO
}

\author{
Dito Pramudyaseta ${ }^{1^{\star}}$, Gres Grasia Azmin² \\ Universitas Negeri Jakarta \\ dito.prams@gmail.com
}

\begin{abstract}
Abstrak
Penelitian ini bertujuan untuk membongkar bagaimanakah realitas sosial perubahan budaya masyarakat yang sedang marak terjadi pada zaman ini yang disinggung dengan lantang dan jelas. Melalui pendekatan sosiologi sastra dan teori yang digagas lan Watt, dapat dilihat alasan mengapa sastra sering disebut sebagai cerminan masyarakat. Landasannya berupa sifat sastra, yang pada hakikatnya tidak dapat dilepaskan dari kenyataan sosial. Metode penelitian ini menggunakan metode kualitatif deskriptif, yakni sebuah penafsiran terhadap karya sastra serta kalimat dan kata-kata yang terdapat di dalamnya yang dibatasi oleh fakta-fakta sosial, yang kemudian diikuti oleh analisis. Hasil penelitian ini menunjukan penggambaran yang terdapat di puisi Keluarga Khong Guan mengenai kenyataan sosial yang sedang terjadi di masyarakat pada bait 2, 3, 4, dan 5, akibat adanya globalisasi dan kemajuan teknologi dan informasi.
\end{abstract}

Kata Kunci: Sosiologi Sastra, Cermin Masyarakat, Joko Pinurbo

\section{PENDAHULUAN}

Karya sastra adalah sebuah seni yang bersandar pada kata-kata atau bahasa sebagai medium untuk menunjukan keindahannya. Selain mengandung keindahan, karya sastra sama seperti seni-seni lainnya, juga mengandung realitas (fakta-fakta) sosial di dalamnya. Baik keindahan atau realitas sosial, keduanya dapat ditampilkan secara langsung atau tidak langsung, tergantung bagaimana pengarang menggunakan bahasa dan kata-kata sebagai alat penyampaian dalam karya sastra itu. Menurut Wiyatmi (2013: 9-10), karya sastra merupakan representasi dari realitas mengenai apa yang terjadi dalam masyarakat.

Bukti adanya hubungan ikatan antara sastra dengan masyarakat adalah lahirnya sebuah ilmu yang bernama sosiologi sastra (Sociology of Literature). Agar dapat lebih memahami apa itu sosiologi sastra, sangat penting untuk kita mengetahui apa arti dari sosiologi itu sendiri. Secara singkat, sosiologi menurut Damono (1978: 6) diartikan sebagai "telaah yang obyektif dan ilmiah tentang manusia dalam masyarakat; telaah tentang lembaga dan proses sosial." Kemudian saat digabung dengan sastra, menurut Ratna (2013: 2) sosiologi sastra diartikan sebagai ilmu yang bersandar pada "pemahaman terhadap sebuah karya sastra dengan mempertimbangkan aspek-aspek kemasyarakatan yang ada di dalamnya". Menurut KBBI, sosiologi sastra adalah sastra karya para kritikus dan sejarawan yang terutama mengungkapkan pengarang yang dipengaruhi oleh status lapisan masyarakat tempat ia berasal, ideologi politik dan sosialnya, kondisi ekonomi serta khalayak yang ditujunya. Jadi, dapat disimpulkan bahwa sosiologi sastra adalah kajian sastra dengan mempertimbangkan aspek-aspek sosial masyarakatnya. Bisa dari hal yang berhubungan dengan penciptanya, gambaran masyarakat yang berada di dalam karya itu, maupun hubungannya dengan para pembaca karya tersebut.

Karya sastra seperti puisi, novel, cerpen, naskah drama atau bentuk-bentuk lainnya adalah wadah yang berisi ungkapan ide, perasaan, pengalaman, dan keyakinan seorang pengarang yang disampaikan dalam bahasa atau kata-kata. Pengarang, sebagai bagian dari masyarakat tempat ia tinggal, cenderung mendapatkan ide dari masyarakat di sekelilingnya. Maka dari itu sastra tidak bisa dilepaskan dari sifatnya sebagai cermin sosiologis pengarang atau masyarakat tempat hidup si pengarang itu. Sebagai cermin masyarakat, sastra terbiasa menggambarkan hal-hal apa saja yang terjadi di tengah-tengah masyarakat. Maka dari itu di dalam karya sastra sering sekali dengan mudah 
kita temui isi atau makna kandungannya yang menyenggol topik-topik sosial masyarakat. Ini bukanlah gejala baru, sudah lama terjadi. Di berbagai macam periode waktu penciptaan karya satra, dapat dengan mudah ditemukan karya-karya sastra yang digunakan untuk menyuarakan isu-isu sosial yang memang sedang relevan di periode waktu itu. Keadaan masyarakat dijadikan inspirasi oleh sang pengarang untuk menghasilkan sebuah karya sastra.

Sastra sebagai cermin masyarakat pernah disampaikan oleh lan Watt. Menurut lan Watt dalam esainya yang berjudul "Literature an Society" dikutip Damono (1978: 3), sosiologi sastra itu diklasifikasikan pada tiga masalah, yakni dari konteks sosial pengarang karya sastra, karya sastra sebagai cermin masyarakat, dan fungsi sosial karya sastra. Pada pembahasan masalah sosiologi sastra klasifikasi kedua, dibahas sastra dalam artian sebagai cermin masyarakat. Sastra sebagai cermin masyarakat lebih menganggap sastra sebagai sebuah dokumenter yang isinya dapat menggambarkan masyarakat. Sastra dianggap sebagai potret yang memberitahu kehidupan masyarakat saat karya sastra tersebut lahir. Lalu, terdapat beberapa hal yang perlu diperhatikan untuk memahami tentang sastra sebagai cermin masyarakat. Pertama, karya sastra mungkin sudah tidak dapat dikatakan mencerminkan masyarakat di saat waktu ditulis akibat banyaknya ciri-ciri masyarakat yang ditampilkan sudah tidak berlaku lagi (terjadi perubahan). Kedua, sifat pengarang yang cenderung mempengaruhi pemilihan dan juga penampilan gambaran kehidupan sosial dalam karyanya. Ketiga, karya sastra tersebut merupakan gambaran sosial mengenai suatu masyarakat tertentu, bukan gambaran sosial seluruh mayarakat. Keempat, yang terakhir, sastra yang berusaha untuk menggambarkan masyarakat secermat-cermatnya mungkin tidak dapat dipercaya sebagai cermin dari masyarakat. Sebaliknya, sastra yang sama sekali tidak bertujuan menggambarkan masyarakat mungkin masih dapat digunakan sebagai cermin masyarakat: mendapatkan informasi tentang masyarakat tertentu.

Beberapa contoh pembahasan karya sastra dari segi sosiologi sastra sebagai cermin masyarakat: novel Siti Nurbaya yang membahas mengenai budaya kawin paksa di masyarakat, novel Sebuah Kapal karya Nh. Dini yang membahas tentang kehidupan seorang diplomat, puisi Nyanyian Angsa karya Rendra yang isinya kehidupan pelacur, puisi Seonggok Jagung karya dari Rendra yang isinya mengenai kehidupan mahasiswa, novel Ronggeng Dukuh Paruk karya Ahmad Tohari mengenai kehidupan ronggeng, novel Merahnya Merah karya Iwan Simatupang mengenai kehidupan kaum gelandangan, novel Belenggu karya Armijn Pane tentang kehidupan seorang dokter, novel Burungburung Manyar karya Y.B. 7 mengenai kehidupan seorang ilmuwan, dan novel Para Priyayi karya dari Umar Kayam mengenai kehidupan seorang guru (Suwardi, 2011: 18). Dari contoh-contoh ini, dapat dilihat bagaimana karya sastra itu menggambarkan kehidupan masyarakat atau suatu kelompok masyarakat tertentu pada suatu masa periode tertentu. Dengan karya sastra, berbagai topik dapat diangkat menjadi perbincangan.

Sastra mengikuti perubahan zaman. Misalnya saat ini karya sastra yang isinya mengangkat topik globalisasi dan dampak akibatnya. Menurut Wuryan dan Syaifullah (2008: 141), secara etimologis, globalisasi berasal dari kata "globe" yang berarti bola dunia, sedangkan akhiran -sasi mengandung makna "proses" atau keadaan yang sedang berjalan/terjadi saat ini. Jadi, secara etimologis globalisasi mengandung pengertian sebuah proses mendunia yang sedang terjadi saat. Menyangkut berbagai bidang dan aspek kehidupan masyarakat, bangsa dan juga negara-negara di dunia. Globalisasi dapat terwujud akibat majunya teknologi dan informasi. Selain dampak baik, globalisasi juga memiliki dampak buruk (Tasnim, Wahyudhi, Silalahi, dkk, 2020). Pertama, menciptakan kolonialisme. Maksud dari kolonialisme ini merujuk pada ketidakseimbangan antara arus informasi dari negara maju dan dari negara berkembang. Akibatnya masyarakat yang berasal dari negara tidak berkembang lebih sering mengonsumsi informasi dari negara yang maju. Sehingga memungkinkan terjadinya kolonialisme (contohnya perubahan dalam gaya hidup). Kedua, menciptanya sebuah ketergantungan. Dengan segala kemudahan yang ditawarkan saat ini, masyarakat enggan menggunakan cara-cara manual dan lebih mementingkan efektivitas dan efisiensi. Ketiga, perubahan sistem nilai dan norma. Dengan akses internet, masyarakat cenderung terbawa ke arah kerusakan bila dibiarkan bebas, bila tidak dibatasi atau diawasi.

\section{METODE PENELITIAN}

Dalam penelitian ini, puisi Keluarga Khong Guan karya Joko Pinurbo dipilih sebagai objek penelitian. Puisi ini diambil dari buku "Perjamuan Khong Guan: Kumpulan Puisi" yang dirilis pada 
REALITAS SOSIAL DALAM PUISI "KELUARGA KHONG.... $\mid 3$ tahun 2020. Penulis memilih puisi Keluarga Khong Guan dikarenakan puisi ini sangat kental akan gambaran masyarakat yang sedang terjadi saat ini akibat globalisasi dan kemajuan teknologi dan informasi seperti internet. Berikut isi puisinya secara keseluruhan:

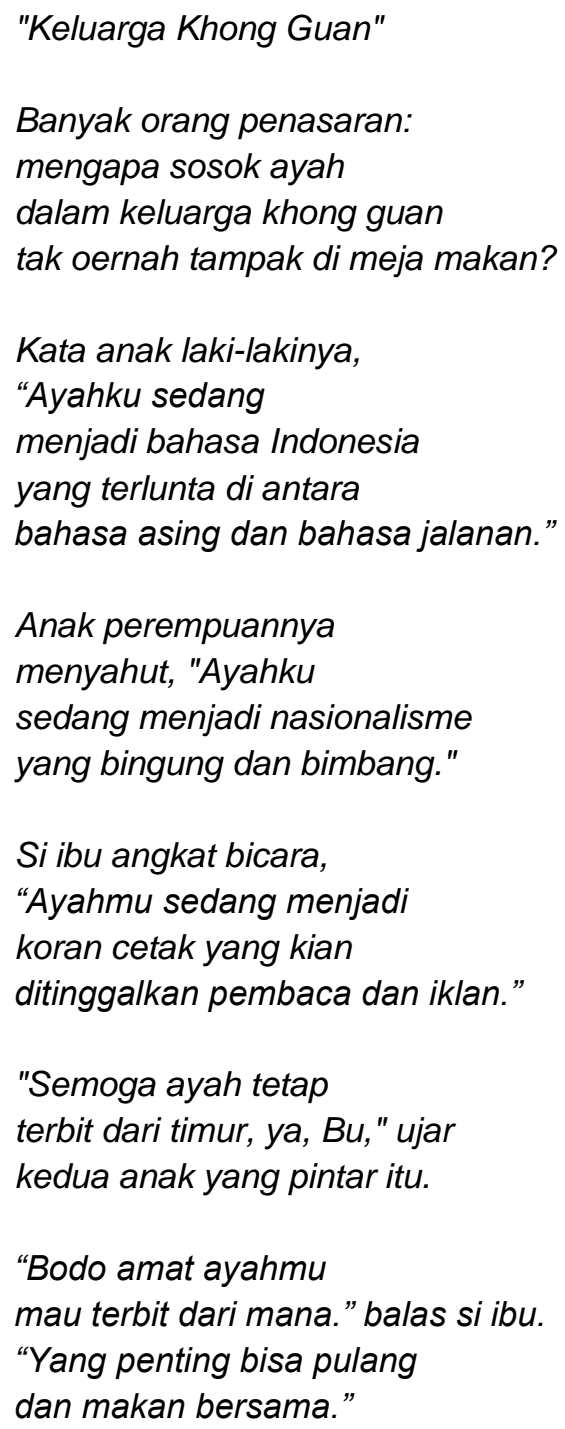

(Jokpin, 2019)

Penelitian ini berlandaskan teori sastra sebagai cermin masyarakat yang disampaikan oleh lan Watt, sehingga tidak semua bait dalam puisi Keluarga Khong Guan digunakan oleh penulis sebagai sumber data. Sumber data yang digunakan dalam analisis ini hanya bait, kalimat atau kata di dalam puisi Keluarga Khong Guan karya Joko Pinurbo yang bermaksud untuk menyinggung keadaan masyarakat saat ini. Dari enam bait di atas, penulis hanya hanya menemukan empat bait yang dapat dijadikan sebagai sumber data dalam penelitian ini. Keempat bait itu adalah bait kedua, ketiga, keempat, dan kelima. Penarikan sampel pada penelitian ini dilakukan penulis dengan cara membaca sungguh-sungguh puisi Keluarga Khong Guan ini, setelah itu ditentukan mana bait yang berisi gambaran realitas sosial sesuai observasi penulis terhadap keadaan masyarakat saat ini.

Seperti yang disebutkan sebelumnya, keindahan atau realitas sosial karya sastra itu dapat ditampilkan secara langsung atau tidak langsung. Semua itu tergantung bagaimana pengarang menggunakan bahasa dan kata-kata sebagai alat penyampaian dalam karya sastra itu. Dalam puisi Keluarga Khong Guan ini, dari empat bait puisi yang dipilih sebagai data penelitian, dapat dilihat bahwa Joko Pinurbo (atau yang lebih dikenal dengan sebutan Jokpin) pada bait kedua, ketiga, dan keempat menggunakan analogi. Jokpin menganalogikan masalah-masalah sosial tersebut dengan tokoh "ayah" Khong Guan yang tidak pernah muncul di gambar kaleng Khong Guan. Lalu, khusus untuk bait kelima, gambaran masyarakat disampaikan dengan simbolis.

Metode yang digunakan dalam penelitian ini adalah metode kualitatif deskriptif. Dalam analisis karya sastra, metode kualitatif deskriptif adalah sebuah penafsiran terhadap kalimat atau kata-kata 
yang terdapat didalam karya sastra. Penafsiran dibatasi oleh fakta-fakta sosial, yang lalu dilanjuti dengan analisis.

\title{
HASIL DAN PEMBAHASAN
}

\section{Ayah sebagai Bahasa}

\author{
Kata anak laki-lakinya, \\ "Ayahku sedang \\ menjadi bahasa Indonesia \\ yang terlunta di antara \\ bahasa asing dan bahasa jalanan”.
}

Pada bait kedua ini tokoh "ayah" dianalogikan sebagai bahasa Indonesia. Bait kedua ini merekam keadaan masyarakat saat ini. Realitas sosial yang diungkapkan adalah tentang bagaimana saat ini bahasa Indonesia sedang terlunta-lunta di tengah bahasa asing dan bahasa jalanan (biasa dikenal dengan bahasa gaul atau bahasa slank). Penggunaan bahasa Indonesia yang baik dan benar memang menjadi masalah tersendiri yang sangat merisaukan, mengingat banyaknya masyarakat yang masih sering salah dalam penerapannya. Tidak hanya masalah dalam penggunaan tanda baca yang benar, tetapi juga masalah penyelipan kata-kata bahasa asing atau bahasa gaul dalam penggunaan bahasa Indonesia, yang sekarang ini sudah sering dilakukan anakanak muda. Anak-anak muda zaman lebih sering menggunakan bahasa asing dan bahasa gaul dibanding bahasa Indonesia. Dari bait kedua ini dapat dilihat bagaimana perkembangan zaman mengubah pola pikir orang-orang dalam penggunaan bahasa sebagai alat komunikasi dan eksistensi diri.

Seperti yang kita ketahui, di zaman globalisasi ini teknologi berkembang dengan sangat cepat dan penggunaan internet oleh masyarakat meningkat pesat, tidak hanya oleh para remaja, tetapi juga oleh orang-orang dewasa. Internet saat ini memang sedang digandrungi oleh hampir seluruh lapisan masyarakat. Internet sebagai suatu jaringan komunikasi berfungsi untuk menghubungkan berbagai jenis orang dari berbagai belahan dunia. Orang-orang akan saling terhubung satu sama lain, sehingga memungkinkan terjadinya sebuah interaks. Internet membuat komunikasi antar manusia-manusia di seluruh pelosok dunia dapat dilakukan dengan mudah, tidak terikat waktu ataupun tempat. Walau begitu, dalam pelaksanaannya tetap dibutuhkan satu bahasa yang dapat menunjang jalannya komunikasi tersebut. Bahasa Inggris sebagai bahasa internasional nomor satu di dunia menjadi jawaban untuk masalah ini. Alhasil, bahasa Inggris mulai berkembang dan berpindah fungsinya: mulai biasa digunakan pada kehidupan sehari-hari masyarakat.

Selain itu, Internet dan sosial media bagi kebanyakan remaja adalah tempat pembentukan citra diri mereka. Mereka akan memilih mana citra yang memberikan dampak positif pada kehidupan sosial mereka di mata masyarakat dunia maya. Seperti yang kita tahu, bukan rahasia umum lagi kalau seseorang masih sering "dilirik" dari seberapa hebat kemampuan bahasa Inggrisnya. Kalau bahasa Inggrisnya hebat, pasti orang itu dianggap keren. Alhasil, media-media sosial seperti facebook, instagram, twitter, menjadi tempat lomba adu keren-kerenan untuk menunjukkan seberapa hebatnya mereka dalam menggunakan bahasa Inggris. Hal ini tidak hanya berlaku pada bahasa Inggris saja, tetapi juga bahasa gaul. Katanya, bahasa gaul itu penting untuk eksistensi diri tiap remaja. Banyak yang menggunakan bahasa gaul agar tidak kampungan dan terlihat "berbeda". Di internet kita akan dengan mudah bertemu dengan orang-orang seperti itu. Bahasa gaul ini kadang sulit untuk di mengerti oleh orang-orang di usia tua karena bahasa gaul ini tidak dapat ditemukan artinya di KBBI. Biasanya, bahasa gaul lahir dari suatu komunitas tertentu sebelum kemudian menyebar melalui internet.

Selain bahasa Inggris dan bahasa gaul, bahasa asing yang lain juga ikut berkembang penggunaannya di tengah-tengah masyarakat. Misal bahasa Korea yang mulai terkenal setelah adanya Hallyu (atau Korean wave). Istilah tersebut merujuk kepada budaya pop Korea Selatan yang tersebar secara global di berbagai negara di dunia, termasuk di Indonesia (Shim, 2006). Penyebaranya melalui film, serial, musik, dan hal-hal lainnya. Karena memakai medium bahasa Korea sebagai bahasa pengantarnya, semua produk tersebut berhasil membuat bahasa Korea mulai dikenal masyarakat luas, dan tentunya berhasil membuat remaja-remaja tertarik untuk 
REALITAS SOSIAL DALAM PUISI "KELUARGA KHONG.... $\mid 5$ mempelajarinya dan menerapkannya. Lalu contoh lain ada bahasa Arab, yang penggunaannya semakin sering kita lihat. Meningkatnya penggunaan bahasa Arab ini sering dikaitkan dengan keinginan umat muslim untuk memperdalam ilmu-ilmu agama. Sebagai negara dengan populasi muslim terbanyak di dunia, hal ini memang tidak terlalu mengejutkan. Hal yang perlu diperhatikan adalah bagaimana penggunaan bahasa Arab ini sering dikaitkan dengan tingkat kesalehan seseorang atau sesuatu. Misal di toilet masjid, kata "pria" dan "wanita" sudah diganti menjadi Ikhwan dan akhwat agar terlihat lebih Islami. Hal ini tentu mengganggu fungsi dari bahasa Indonesia sebagai alat komunikasi masyarakat.

\title{
Ayah sebagai Semangat Nasionalisme
}

\author{
Anak perempuannya \\ menyahut, "Ayahku \\ sedang menjadi nasionalisme \\ yang bingung dan bimbang".
}

Pada bait ketiga ini, ayah keluarga Khong Guan diibaratkan sebagai semangat nasionalisme yang saat ini semakin terkikis. Nasionalisme secara umum diartikan sebagai suatu perasaan cinta tanah air seseorang, yang dilandasi rasa bangga dan kepemilikan terhadap negeri tempat tinggal dan tumbuh berkembang orang tersebut. Rasa bangga dan kepemilikan tersebut tentu tidak hanya lahir begitu saja. Demi menghasilkan individu-individu yang dapat menunjukkan loyalitas dan pengabdian untuk bangsa dan tanah airnya, rasa bangga dan kepemilikan tersebut ditanamkan sejak masuk ke dunia pendidikan. Misal di Indonesia melalui upacara bendera, atau di lingkungan rumah dengan perayaan 17 Agustusan (hari Kemerdekaan), sehingga anak-anak memahami betapa pentingnya perjuangan para pahlawan dalam merebut kemerdekaan.

Di era globalisasi ini, dengan majunya teknologi dan internet, rasa nasionalisme seseorang mulai menipis akibat banyaknya paham-paham lain yang masuk. Internet sebagai tempat bertemunya orang-orang dari seluruh dunia, memungkinkan komunikasi lintas budaya antar masyarakat dunia. Pada akhirnya akan terbentuk suatu kebudayaan baru di masyarakat (westernisasi), dengan nilai-nilai berpikir dan bersikap yang tak jarang berlawanan dengan rasa nasionalisme yang sebelumnya dipegang. Nilai asli masyarakat Indonesia pun mulai luntur. Akibatnya anak-anak Indonesia yang tumbuh di masa depan pun akan bingung seperti apa identitas masyarakat Indonesia yang sebenarnya.

Selain itu, masalah-masalah lain seperti munculnya kelompok-kelompok yang ingin memisahkan diri dari Indonesia atau mengganti ideologi Pancasila dengan ideologi lain juga menjadi masalah yang sangat mengancam persatuan Indonesia. Contohnya yang sering sekali disuarakan akhir-akhir ini yakni mengganti Pancasila dengan sistem khilafah. Bila hal itu terjadi maka suatu kelompok tertentu akan merasa "lebih tinggi" dibanding dengan kelompok lain, atau sebaliknya, kelompok tertentu akan merasa "lebih rendah" dibanding kelompok lain. Akan ada pemikiran bahwa salah satu kelompok memiliki hak lebih dibanding kelompok yang lainnya. Hal ini tentu akan berbahaya bagi persatuan Indonesia.

Semua isu tersebut akan semakin berbahaya bila dimanfaatkan oleh kelompok-kelompok tertentu agar Indonesia terpecah belah. Indonesia yang sangat beragam tentu sangat sensitif dengan isu-isu yang dapat menyenggol permasalahan agama, suku, atau etnis. Semua ini terjadi akibat minimnya integrasi nasional, yakni suatu upaya untuk menyatukan bangsa yang terdiri dari berbagai suku menjadi satu identitas besar yang utuh. Integrasi nasional menjadi suatu hal yang penting dikarenakan dengan kesatuan identitas itu akan muncul tujuan untuk menjaga dan membangun bangsa bersama. Ideologi Pancasila sudah berusaha mengikat identitas itu. Hal yang membuat Indonesia "menjadi" Indonesia ialah keberagamannya yang bersatu padu di bawah Panji merah putih. Pancasila bagi masyarakat Indonesia adalahi payung bagi keragaman tersebut. Bila Pancasila diganti dengan ideologi lain, hal itu akan menghilangkan identitas Indonesia dan akan mengakibatkan perpecahan. 


\title{
Ayah sebagai Koran Cetak
}

\author{
Si ibu angkat bicara, \\ "Ayahmu sedang menjadi \\ koran cetak yang kian \\ ditinggalkan pembaca dan iklan".
}

Pada bait keempat ini, karakter ayah dianalogikan sebagai koran cetak yang dari hari ke hari mulai kehilangan pembaca dan iklan (merujuk pada orang yang menaruh iklan/berpromosi). Menyinggung fenomena sosial yang terjadi pada zaman ini, yakni turunnya tingkat penggunaan koran cetak oleh masyarakat yang biasanya digunakan sebagai wadah untuk mencari berita-berita terbaru. Seperti yang kita tahu, media-media cetak seperti koran, majalah, atau tabloid adalah barang yang menemani keseharian masyarakat. Ditambah dengan segelas kopi atau teh hangat, mereka senantiasa menjadi bahan bacaan di pagi hari bagi masyarakat sebelum memulai aktivitas. Namun, setelah pesatnya peningkatan penggunaan internet oleh masyarakat, penggunaan mediamedia cetak untuk mencari berita atau bahan bacaan menjadi turun secara drastis. Masyarakat sekarang mulai berpindah dan beralih ke internet. Internet memang memiliki banyak sekali kelebihan. Selain berisi berita-berita terbaru, internet juga berisi berita-berita masa lampau. Dengan kata lain, berita di internet tidak terikat waktu atau ataupun tempat. Berita yang ditemukan juga lebih bervariasi, sesuai apa yang ingin kita cari tahu.

Selain berisikan berita-berita terbaru, media-media cetak juga berisikan iklan, baik itu iklan produk atau iklan penyediaan jasa. Bahkan, di berita juga sering ditemukan lowongan-lowongan pekerjaan yang tentu dapat memudahkan para pencari kerja untuk menemukan pekerjaan yang mereka sukai. Pihak penerbit tahu bahwa koran dan media-media cetak lainnya menjangkau banyak kalangan masyarakat, maka dari itu iklan produk, jasa, atau lowongan sangat cocok ditaruh di dalamnya. Banyak orang yang akan melihatnya. Lalu, adanya promosi-promosi pada media cetak tersebut juga bukan tanpa alasan. Biasanya penghasilan penjualan yang didapat dari para pembaca tidak terlalu menguntungkan pihak penerbit, maka dari itu pihak penerbit memperbolehkan media cetak mereka digunakan oleh pihak-pihak lain untuk melakukan promosi. Itu merupakan salah satu sumber penghasilan bagi pihak penerbit media cetak. Dengan tambahan penghasilan tersebut, pihak penerbit pun tetap dapat meneruskan usaha mereka. Promosi-promosi ini tentu tidak hanya menguntungkan pihak penerbit, tetapi juga menguntungkan pihak "penaruh" iklan. Seperti yang sebelumnya disebutkan, dengan pengiklanan di media cetak, pihak penaruh iklan tetap dapat memperkenalkan produknya ke masyarakat tanpa perlu memikirkan biaya yang tinggi seperti saat melakukan pengiklanan di TV atau radio.

Bagi yang ingin produk jualannya menjangkau tiap lapisan masyarakat tanpa biaya yang tinggi, media cetak memang menjadi tempat favorit, setidaknya sebelum adanya kehadiran internet. Dengan kehadiran internet, promosi-promosi pada media cetak yang sebelumnya ramai berubah menjadi sepi. Dengan alasan murah (bahkan gratis), jangkauannya lebih luas dan mudah: bisa dilakukan kapanpun dan juga di manapun, internet menjadi tempat yang paling menguntungkan dan paling efisien untuk melakukn promosi. Media cetak pun mulai ditinggalkan oleh para pengiklan, dan para pihak penerbit semakin menurun hasil pendapatannya. Ditinggalkan para pembaca dan para pengiklan tentu membuat pihak penerbit rugi. Bahkan bisa sampai bangkrut dan kemudian gulung tikar. Memang benar, hanya yang mau berkembang yang bisa bertahan mengikuti perubahan masyarakat.

\section{Ayah sebagai Matahari}

\author{
Semoga ayah tetap \\ terbit dari timur, ya, Bu," ujar \\ kedua anak yang pintar itu.
}

Pada bait kelima ini tokoh "ayah" dianalogikan sebagai "masyarakat" juga. Tetapi, tidak seperti tiga bait sebelumnya yang meneriakkan perubahan keadaan sosial masyarakat secara langsung, bait kelima ini menggambarkan perubahan masyarakat secara simbolis. "Semoga ayah tetap terbit dari timur" merupakan simbolis yang dapat diartikan sebagai harapan agar masyarakat (Indonesia) tetap hidup dengan menganut nilai budaya timur. Harapan ini tentu muncul akibat banyaknya 
REALITAS SOSIAL DALAM PUISI "KELUARGA KHONG.... 7 masyarakat kita yang mulai berubah dalam bersikap dan berperilaku di kehidupan sehari-hari, terutama anak-anak remaja. Anak-anak remaja Indonesia saat ini mulai bersikap dan berperilaku seperti orang barat. Mereka mulai melupakan budaya asli mereka. Di kehidupan sehari-hari mereka mulai melupakan nilai kesopanan, misalnya dalam hal berpakaian. Mereka juga mulai mengenal minuman keras, obat instan terlarang, juga seks di luar nikah. Dengan dalil hal itu tidak merugikan orang-orang sekitar, mereka tidak hanya membenarkan perbuatan itu, tetapi juga mulai menormalisasikannnya. Mereka mulai lebih mementingkan ego sendiri dan tidak mempedulikan seperti apa budaya masyarakat yang dijunjung.

Sama seperti tiga bait sebelumnya, perubahan keadaan masyarakat saat ini juga terjadi akibat gencarnya penggunaan internet di era globalisasi ini. Dengan internet digenggaman tangan mereka, anak-anak remaja mulai dipengaruhi budaya dari negara-negara barat. Lama-kelamaan mereka pun mulai berubah dan melupakan budaya asli mereka. Hal ini tentu mengkhawatirkan mengingat Indonesia menjunjung budaya timur. Seperti yang kita tahu, budaya timur merujuk pada nilai-nilai budaya yang ada dan diterapkan di wilayah Benua Asia. Budaya timur tentu memiliki nilai-nilai tersendiri yang membedakannya dengan budaya barat. Apa yang dapat diterima oleh orang timur, belum tentu dapat diterima oleh orang barat. Begitu juga sebaliknya. Apa yang dapat diterima oleh orang barat, belum tentu dapat diterima oleh orang timur. Perbedaan kedua budaya ini terjadi karena perbedaan leluhur dan nilai-nilai yang diturunkannya.

\section{PENUTUP}

Berdasarkan hasil analisis puisi Keluarga Khong Guan karya Joko Pinurbo dapat kita lihat empat realitas sosial yang terjadi saat ini akibat globalisasi dan berkembang pesatnya teknologi dan informasi, yang selalu dihubungkan dengan tokoh "ayah" yang tidak pernah terlihat dalam kaleng Khong Guan. Pada bait kedua menggambarkan keadaan bahasa Indonesia saat ini. Saat ini, masyarakat lebih bangga menggunakan bahasa asing atau bahasa gaul. Selain kedua bahasa tersebut, berkembang juga penggunaan bahasa-bahasa lainnya. Hal ini sangat mengkhawatirkan mengingat penyelipan bahasa asing dan bahasa gaul tersebut mulai dibiasakan dalam hal-hal yang seharusnya menggunakan bahasa Indonesia sebagai bahasa persatuan.

Pada bait ketiga menggambarkan semangat nasionalisme masyarakat Indonesia yang semakin menurun. Beragam isu yang mengganggu kedaulatan negara menjadi santapan harian di berita-berita. Isu mengganti ideologi Pancasila dengan ideologi lain, isu ingin lepasnya suatu daerah dari NKRI, dan isu-isu sensitif lainnya yang sangat mengkhawatirkan. Belum lagi pihak-pihak tertentu yang memanfaatkan isu tersebut untuk memecah bekas Indonesia.

Pada bait keempat menggambarkan kondisi koran dan media-media cetak lainnya yang sudah ditinggalkan oleh para pembaca. Pada pembaca saat ini lebih memilih internet sebagai tempat untuk mencari berita. Koran dan media-media cetak lainnya terlihat kuno dibanding kelebihan-kelebihan yang ada di internet. Akibat dari hal ini, koran tidak hanya ditinggalkan para pembaca sejatinya, tetapi juga ditinggalkan para sponsor atau orang-orang yang ingin menaruh iklan. Mereka juga lebih memilih internet sebagai tempat untuk melakukan promosi produk mereka.

Pada bait kelima, masyarakat digambarkan mulai berubah haluan dalam bersikap dan berpikir. Mereka mulai bersikap dan berpikir seperti orang-orang barat. Masyarakat, terutama anak-naka remaja, mulai meninggalkan gaya hidup orang timur akibat sering mengkonsumsi pemikiranpemikiran budaya barat. Mereka melihat kesenangan dari kebebasan gaya hidup barat, sehingga mulai mempraktikkannya dalam kehidupan sehari-hari tanpa melihat tempat.

\section{DAFTAR PUSTAKA}

Agustin, D.S.Y. 2011. Penurunan Rasa Cinta Budaya dan Nasionalisme Generasi Muda Akibat Globalisasi. jsh Jurnal Sosial Humaniora.

Ariyanti, Novi. 2019. Kajian Sosiologi Sastra pada Tokoh Utama dalam Novel al-Rajul al-Ladzi Amana Karya Najib al-Kaelani. Jurnal Arabiyatuna.

Damono, Sapardi Djoko. 1978. Sosiologi Sastra Sebuah Pengantar Ringkas. Jakarta: Pusat Pembinaan dan Pengembangan Bahasa.

Dito Pramudyaseta, Gres Grasia Azmin 
Hardiansyah, Tamarli, dan Hasanah. 2019. Pergeseran Nilai-Nilai Budaya Lokal pada Masyarakat. Kandidat.

Hendrastomo, Trendi. 2007. Nasionalisme vs Globalisasi 'Hilangnya' Semangat Kebangsaan dalam Peradaban Modern. Dimensia.

Islamiah, Nur. Dampak Negatif Budaya Asing pada Gaya Hidup Remaja Kota Makassar. Tugas Skripsi. UIN Alauddin Makassar.

Kurniasari, L.P., Sholehhudin, M., dan Setiyono, J. 2019. Analisis Sosiologi Sastra Novel Sunyi Nirmala Karya Ashadi Siregar dan Hubungannya dengan Pembelajaran di SMA. Jurnal Genre.

Murti, Sri. 2015. Eksistensi Penggunaan Bahasa Indonesia di Era Globalisasi. Prosiding Seminar Nasional Bulan Bahasa 2015. Unit Penerbitan FKIP Universitas Bengkulu.

Nuraidah, dan Musa, M.I. 2015. Dampak Pengaruh Globalisasi Bagi Kehidupan Bahasa Indonesia. Jurnal Pesona Dasar.

Pinurbo, Joko. 2020. Perjamuan Khong Guan: Kumpulan Puisi. Jakarta: PT Gramedia Pustaka Utama.

Pradono, Winda. 2015. Pengaruh Budaya K-Pop terhadap Nasionalisme Remaja (Studi Deskriptif Analitis di Everlasting Friends (ELF) Bandung).

Putri, I.P., Liany, F.D.P., dan Nuraeni, R. 2019. K-Drama dan Penyebaran Korean Wave di Indonesia. ProTVF

Ratna, Nyoman Kutha. 2013. Stilistika Kajian Puitika Bahasa, Sastra, dan Budaya. Yogyakarta: Pustaka Pelajar.

Romadhon, B.A. 2018. Meredupnya Media Cetak, Dampak Kemajuan Teknologi Informasi. Jurnal An-Nida.

Sakti, B.C., dan Yulianto, M. 2018. Penggunaan Media Sosial Instagram dalam Pembentukan Identitas Diri Remaja. Interaksi Online.

Sari, B.P. Dampak Penggunaan Bahasa Gaul di Kalangan Remaja terhadap Bahasa Indonesia. Prosiding Seminar Nasional Bulan Bahasa UNIB 2015. FKIP Universitas Bengkulu.

Shim, D. 2006. Hybridity and the Rise of Korean Popular Culture in Asia. Media, Culture and Society, Vol. 28, pp. 25-44.

Sudarsono, A., dan Wijayanti, A.T. 2016. Pengantar Sosiologi. Yogyakarta: Universitas Negeri Yogyakarta.

Supardan, Dadang. 2011. Tantangan Nasionalisme Indonesia dalam Era Globalisasi. Jurnal LENTERA Jurnal IImu-IImu Sejarah, Budaya, dan Sosial.

Suwardi. 2011. Sosiologi Sastra. Yogyakarta: Universitas Negeri Yogyakarta.

Tasnim., Wahyudhi, S., Silalahi, M., Gandasari, D., Sari, M., Sahri, S., Purba, P.B., Sari, A.P., dan Simarmata, J. 2020. Pengantar Komunikasi Organisasi. Penerbit: Yayasan Kita Menulis.

Wiyatmi. 2013. Sosiologi Sastra. Kanwa Publisher.

Wuryan, Sri dan Syaifullah. 2008. IImu Kewarganegaraan (Civics). Bandung: Laboratorium Pendidikan Kewarganegaraan. 